Mini review

\title{
Induced resistance during the interaction pathogen $x$ plant and the use of resistance inducers
}

\author{
M.D.M. Oliveira*, C.M.R. Varanda, M.R.F. Félix \\ Laboratório de Virologia Vegetal, Instituto de Ciências Agrárias e Ambientais Mediterrânicas, Universidade de Évora, Apartado 94, 7002-554 Évora, Portugal
}

\section{A R T I C L E I N F O}

\section{Article history:}

Received 9 June 2015

Received in revised form 28 October 2015

Accepted 30 December 2015

Available online $\mathrm{xxx}$

Keywords:

Exogenous resistance inducers

Plant defence

Pathogens

\begin{abstract}
A B S T R A C T
Plants react to aggressions through different defence responses. Mechanical barriers consist in the increase of production and deposition of substances capable of containing pathogen invasion. Chemical barriers consist in the increase of concentration or activity of defence proteins and synthesis of phenolic compounds and phytoalexins. Elicitor substances have been widely used in plant disease control showing impressive results and a low impact to the environment and man. This review contains information about plant defence mechanisms and shows the use of inducers of resistance in the control of pathogens and prospects of advance towards sustainable agriculture.
\end{abstract}

(c) 2016 Phytochemical Society of Europe. Published by Elsevier B.V. All rights reserved.

\section{Contents}

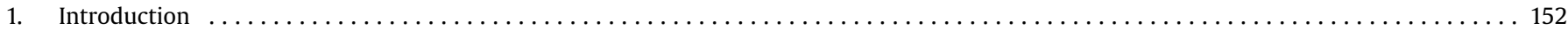

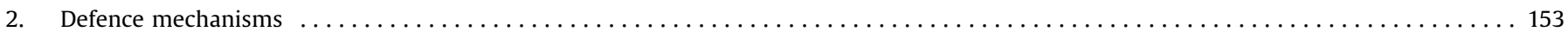

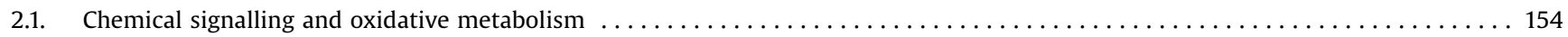

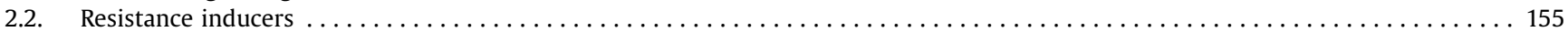

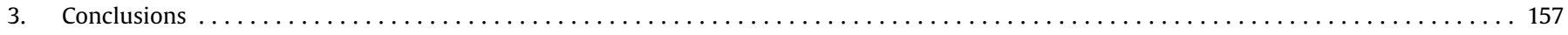

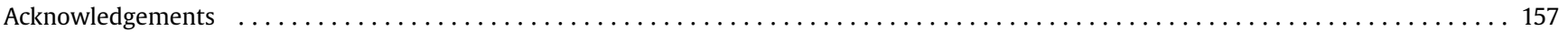

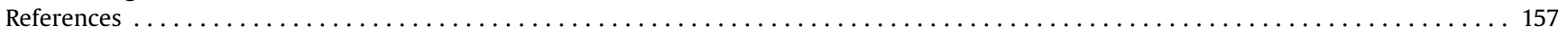

\section{Introduction}

During the evolutionary process, plants have developed mechanisms to respond to different types of stress, either abiotic, such as drought, salinity and high temperature (Shah et al., 2014), or biotic, such as pathogens (Shah and Zeier, 2013). These defence mechanisms remain inactive or latent until they are activated after exposure and/or contact with inducing agents (Mandal, 2010).

Plants have several defence mechanisms against pathogens. The octadecanoid pathway is one of the best known mechanisms in plant defence, and its final product, the jasmonic acid is a plant hormone that induces the expression of several genes related to defence against stress (Shah et al., 2014). Additionally, this pathway induces the production of $\mathrm{H}_{2} \mathrm{O}_{2}$, a reactive oxygen species (ROS) that can act as a first defence signalling molecule in

\footnotetext{
* Corresponding author.

E-mail address: monicadmportella@hotmail.com (M.D.M. Oliveira).
}

plants. A number of other reactive species, as well as several antioxidant enzymes, are constantly modulated in the presence of a certain stress in order to overcome it (Vandenborre et al., 2011; O'Brien et al., 2012; Davar et al., 2013; Raoni and Pratyusha, 2013).

The infection caused by a pathogen may induce dramatic changes in the activity of plant cells around the site of invasion and may lead to the induction of resistance, known as the hypersensitive response (HR), characterised by rapid cell death at the site of infection (Durrant and Dong, 2004). Although this reaction is known for almost a century, it is not yet clear whether cell death has any direct role in resistance or if it is a consequence of signalling mechanisms that lead to events that inhibit pathogen action (Thakur and Sohal, 2013).

Systemic acquired resistance (SAR) and induced systemic resistance (ISR) designate the mechanisms by which plants activate defence mechanisms not just in the induction site but also at other places, after being exposed to an inducing agent (Conrath et al., 2006). 
Advances in research involving ISR in plants have been accompanied by the emergence of new commercial products with higher efficiency, stability and with less impact on the environment than existing ones. These new products are able to increase agricultural productivity not only by reducing the losses caused by pathogens but also by increasing vegetative growth (Farouk and Osman, 2011).

Acibenzolar-S-methyl (ASM) was the first SAR inductor released for commercial use (Lyon and Newton, 2007). Since then, several other products have become available on the market or are currently being researched (Graham and Myers, 2011). Secondary compounds present in medicinal plants have also been used as resistance inducers due to their important roles in plant-pathogen interactions, either by direct antimicrobial action or by the induction of defence mechanisms in other plants (Garcia-Brugger et al., 2006). This review provides an updated summary of plant defence responses and describe some resistance inducers that are used to induce systemic responses in plants as well as the associated oxidative metabolism.

\section{Defence mechanisms}

Plants have natural resistance mechanisms for defending themselves against pathogenic organisms that are characterised by the resistance ability of the plant to decrease or avoid the establishment of certain populations of pathogens (Farouk and Osman, 2011).

The better understanding of plant signalling pathways has led to the discovery of natural and synthetic compounds called resistance inducers that induce defence responses in plants similar as the ones induced by pathogen infection (Gómez-Vásquez et al., 2004). Different types of resistance inducers have been characterised, including carbohydrate polymers, lipids, glycopeptides, and glycoproteins. In plants, a complex array of defence responses is induced after detection of microorganism via recognition of elicitor molecules released during plant-pathogen interaction. Following elicitor perception, the activation of signal transduction pathways generally lead to the production of reactive oxygen species, phytoalexin biosynthesis, reinforcement of plant cell wall associated with phenyl propanoid compounds, deposition of callose, synthesis of defence enzymes, and the accumulation of pathogenesis-related (PR) proteins, some of which with antimicrobial properties (Van Loon and Van Strien, 1999; Madhusudhan et al., 2008; Aryal et al., 2011; Thakur and Sohal, 2013). ROS lead to hypersensitive response (HR) (Agrios, 2005) in plants which is a rapid death of one or few cells at the infection site to delimit the pathogen growth. Following the activation of HR, uninfected distal parts of the plant may develop resistance to further infection, a phenomenon known as systemic acquired resistance (SAR). SAR is effective against diverse pathogens, including viruses, bacteria, and fungi (Heil and Bostock, 2002; Graham and Myers, 2011; Elsharkawy et al., 2013).

When resistant plants recognize resistance inducers, intracellular signal transduction pathways are activated. These pathways ultimately result in the derepression of a battery of genes called defence response genes. These latter genes encode various pathogenesis related (PR) toxic proteins such as chitinases, glucanases, lysozyme-active proteins, or cell wall strengthening proteins such as hydroxyproline rich glycoproteins. Response proteins may also be enzymes that act in biosynthetic pathways for lignification of cell walls or production of phytoalexins, low molecular weight toxic chemicals that antagonize the invader. In the following section, the biochemical response of plant defence mechanism related to PR-proteins including chitinase and glucanase, as well as plant lignin content will be explained (Ebrahim et al., 2011).
The production and accumulation of PR proteins in plants in response to invading pathogen and/or stress situation is very important (Liu and Ekramoddoullah, 2006). Phytoalexins are mainly produced by healthy cells adjacent to localized damaged and necrotic cells, but PR proteins accumulate not only locally in the infected and surrounding tissues but also in remote uninfected tissues. Production of PR proteins in the uninfected parts of plants can prevent the affected plants from further infection (Ryals et al., 1996; Delaney, 1997; Ebrahim et al., 2011). PR proteins in plants were first discovered in tobacco plants infected with Tobacco mosaic virus (Van Loon and Van Kammen, 1970). At present, these proteins have been found in many plants. Most plant PR proteins are acid-soluble, have low molecular weight, and are proteaseresistant (Leubner-Metzger and Meins, 1999; Neuhaus, 1999). PR proteins depending on their isoelectric points may be acidic or basic proteins but they have similar functions. Most acidic PR proteins are located in the intercellular spaces, whereas, basic PR proteins are predominantly located in the vacuole (Legrand et al., 1987; Niki et al., 1998; Van Loon and Van Strien, 1999). PR proteins have been classically divided into 5 families (Sels et al., 2008) based on molecular mass, isoelectric point, localization and biological activity (Van Loon, 1985). Currently PR-proteins are categorized into 17 families according to their properties and functions, including $\beta$-1,3-glucanases, chitinases, thaumatin-like proteins, peroxidases, ribosome-inactivating proteins defences, thionins, nonspecific lipid transfer proteins, oxalate oxidase, and oxalate-oxidase-like proteins (Van Loon and Van Strien, 1999). Among these PR proteins, chitinases and $\beta$-1,3-glucanases are two important hydrolytic enzymes that are abundant in many plant species after infection by different type of pathogens. They play a main role on defence reactions against fungal pathogens by degrading their cell walls, of which chitin and $\beta-1,3$-glucan are major structural components. $\beta-1,3$-glucanases appear to be coordinately expressed along with chitinases after fungal infection. This co-induction of the two hydrolytic enzymes has been described in many plant species, including pea, bean, tomato, tobacco, maize, soybean, potato and wheat (Mauch et al., 1988a; Mauch et al., 1988b; Vogelsang and Barz 1993; Jach et al., 1995; Bettini et al., 1998; Lambais and Mehdy, 1998; Petruzzelli et al., 1999; Cheong et al., 2000; Li et al., 2001; Ebrahim et al., 2011).

Constituent chemical and anatomical factors such as cuticles and preformed cell walls and inhibitors, may be sufficient to prevent colonization of plant tissues. However, if penetration occurs, the induced defence system is activated. This includes the rapid generation of reactive oxygen species, changes in cell wall polymers, synthesis of low molecular weight metabolites such as phytoalexins, production of new classes of proteins related to the defence and a hypersensitivity response followed by programmed cell death (Thakur and Sohal, 2013). Collectively, these systems first prevent the pathogen entrance and then inhibit the pathogen establishment (Shewry and Lucas, 1997; Thakur and Sohal, 2013).

The induced resistance (IR) can be activated by a number of substances, preventing or delaying the entry or subsequent activity of the pathogen in their tissues (Abdel-Kader et al., 2013; Shah et al., 2014). Several agents can induce the production of "signs" in plant tissues, triggering reactions that culminate in a lasting protection against a wide range of pathogens. The perception occurs when the inducing agent molecules bind to receptor molecules that are probably located in the plasma membrane of the plant cell. These reactions trigger the activation of several defence mechanisms (Graham and Myers, 2011). The IR can be divided into two categories, systemic acquired resistance and induced systemic resistance (Van Loon et al., 1998). In SAR, resistance develops systemically in response to a pathogen that causes necrotic lesions or through exogenous application of salicylic acid or synthetic compounds such as ASM and 
2,6-dichloroisonicotinic acid (INA). In SAR, the expressed resistance is generally effective against a broad spectrum of pathogens and is associated with the synthesis of proteins related to pathogenesis, many of them have antimicrobial activity and are excellent molecular markers for resistance response. SAR is induced by pathogens or chemicals activators (Mandal, 2010), it is characterised by the expression or production of a signal released from the site of infection that causes necrosis and translocation of this signal to other parts of the plant, inducing defence reactions that will protect the plant against subsequent attacks. Cell wall modifications, phytoalexins production and protein translation related to pathogenesis by increasing gene expression, are among the induced defence mechanisms by SAR (Ebrahim et al., 2011).

ISR is usually induced by rhizobacteria and signalling is mediated by jasmonic acid and ethylene (Van Loon et al., 1998; Thakur and Sohal, 2013). In ISR, the inducer does not cause necrotic symptoms at the site of infection, but induces the plant to a systemic protection. In this mechanism, there is no accumulation of pathogenesis-related proteins, the plant that suffers induction does not show alterations, the inducing agent is usually a nonpathogen and induction is not salicylate-dependent, suggesting that there may be another signalling pathway more associated with jasmonates and ethylene (Van Loon et al., 1998; Farouk and Osman, 2011).

According to some authors, although the induction of resistance has great potential in plant protection, it should not be seen as a redeeming solution to all problems, mostly because several steps involved in the activation of induced resistance mechanisms are not yet well studied. In addition, according to some researchers, the use of resistance for a given pathogen may be associated with the inducing effect of susceptibility to pests and herbivores (Bostock, 1999; Cameron, 2000; Mandal, 2010).

\subsection{Chemical signalling and oxidative metabolism}

Different responses can be given to a lesion caused by injury according to the part of the plant affected (Shah et al., 2014). In addition, plants of different ages may present different levels of protein expression in similar vegetative organs (Buchanan et al., 2000) and the physiological state of the plant may also influence the response (Alarcon and Malone, 1995).

In the process of interaction of the pathogen with the plant, it may occur compatibility (susceptibility) or incompatibility (resistance) (Heil and Bostock, 2002). Once an incompatible interaction occurs, a series of responses involving the release of signalling molecules is triggered, starting with the recognition or perception, signal transduction and translation for the activation of defence genes (Bostock, 2005; Walters et al., 2007).

Plants activate several barriers of defence against the attack of pathogens (Jones and Dangl, 2006). The first line of defence is triggered by the recognition of invariant microbial epitopes known as pathogen associated molecular patterns (PAMPs). PAMPs recognize potential pathogens in the innate immune system of both plants and animals. Examples of PAMPs are conserved cell surface structures like flagellin, lipopolysaccharides or peptidoglycanes from gram-negative bacteria or fungal cell wall components like glucan or chitosan. These PAMPs are recognized by distinct cell surface pattern recognition receptors that activate basal or innate immune responses, which is termed PAMPtriggered immunity (PTI). Pathogens (virulent) use effectors (virulence factors) to block this PTI leading to virulence. However, some plant cultivars have evolved specific surveillance proteins, the Resistance $(\mathrm{R})$ proteins, that recognize these effectors (called avirulence - avr - factors and the pathogens being avirulent), mounting a second line of defence called effector-triggered immunity (ETI) (Torres, 2010). ETI is stronger than PTI and usually displays an HR with cell death associated to the pathogen infection (Jones and Dangl, 2006).

Usually of a proteinaceous nature, the receptor is located in the plasma membrane and inside the cell. The receptor mediates the perception signals derived from the elicitor or pathogen, and causes alterations in the cellular metabolism, such as activation of $\mathrm{G}$ proteins, increase of ions flux across the plasma membrane, kinases and phosphatases activity and production of secondary messengers (Garcia-Brugger et al., 2006).

$G$ proteins interact with receptor and increase the affinity for GTP (guanine triphosphate), and when the replacement of GDP (guanine diphosphate) by GTP occurs the protein becomes active, interacting with other plasma membrane proteins, such as the ones that function as ions channels, phosphodiesterases and phospholipases, and this complex (G protein - elicitor receptor plasma membrane proteins) gains the ability to diffuse the signal, inducing the activity of specific intracellular proteins (Bowles, 1990; Ebrahim et al., 2011).

The opening of an ion channel in the plasma membrane occurs due to the interaction elicitor/receptor stimulating an ions flux across the membrane, altering the transmembrane potential and causing the extracellular alkalinisation due to the entry of $\mathrm{H}^{+}$and $\mathrm{Ca}^{2+}$ and exit of $\mathrm{K}^{+}$and $\mathrm{Cl}^{-}$. The entry of $\mathrm{Ca}^{2+}$ in the cell activates oxidative reactions that can act directly in defence and/or trigger other defence reactions (Dixon et al., 1994; Thakur and Sohal, 2013).

The phosphorylation of cytoplasmic proteins by kinases is a key mechanism in the signalling system for intracellular signal transduction, it leads to the stimulation of a membrane oxidase involved in the generation of the superoxide ion, initiating the oxidative burst (production of ROS, including $\mathrm{H}_{2} \mathrm{O}_{2}$ ), direct induction of gene transcription, jasmonic acid biosynthesis (highly variable in concentration in plant tissues) and/or ethylene and apoptosis (Gill and Tujela, 2010; O’Brien et al., 2012).

Salicylic acid, jasmonates, ethylene, nitrous oxide, protein kinases and phosphatases have been reported as being involved in the transduction of signal resistance inducers, converting received signals into specific responses inside the cells (Mandal, 2010; Farouk and Osman, 2011). The hormones involved in defencerelated processes may act alone or together and control each other's effects (Shah et al., 2014). Among the secondary messengers identified as putative mediators of defence responses, one can highlight cAMP, $\mathrm{Ca}^{2+}, \mathrm{Ca}^{2+}$-calmodulins complex, inositol triphosphate protein kinases (IF3) and ROS (O'brien et al., 2012).

The production of ROS is required for hypersensitivity response, $\mathrm{HR}$, or in other words, the programmed death of cells adjacent to the infection, limiting the pathogen access to water and nutrients (Thakur and Sohal, 2013). The main points of production of ROS are chloroplasts and mitochondria, mainly because these organelles have high metabolic oxidation activity and intense electron flow. In chloroplasts, the formation of ROS is related to photosynthesis events. The photorespiration phenomenon in peroxisomes is another form of $\mathrm{H}_{2} \mathrm{O}_{2}$ production. In mitochondria 1-5\% of $\mathrm{O}_{2}$ consumed in dark conditions may be responsible for the production of ROS. Other important sources of ROS production in plants receiving little attention, are the detoxification reactions catalysed by cytochrome P450 in the cytoplasm and endoplasmic reticulum. These reactive species are also generated at the plasma membrane level or extracellularly in the apoplast (Garcia-Brugger et al., 2006; Gill and Tuteja, 2010). In case of virus infections is, sometimes, located in the cytoplasm. (Fig. 1).

Early studies did not detect any reactive oxygen species (ROS) production in systemic tissues during the onset of SAR (Neuenschwander et al., 1995; Ryals et al., 1995). However, In 1998, it was discovered that $\mathrm{H}_{2} \mathrm{O}_{2}$ accumulates in small groups of cells in uninoculated leaves of Arabidopsis after infection with an avirulent 


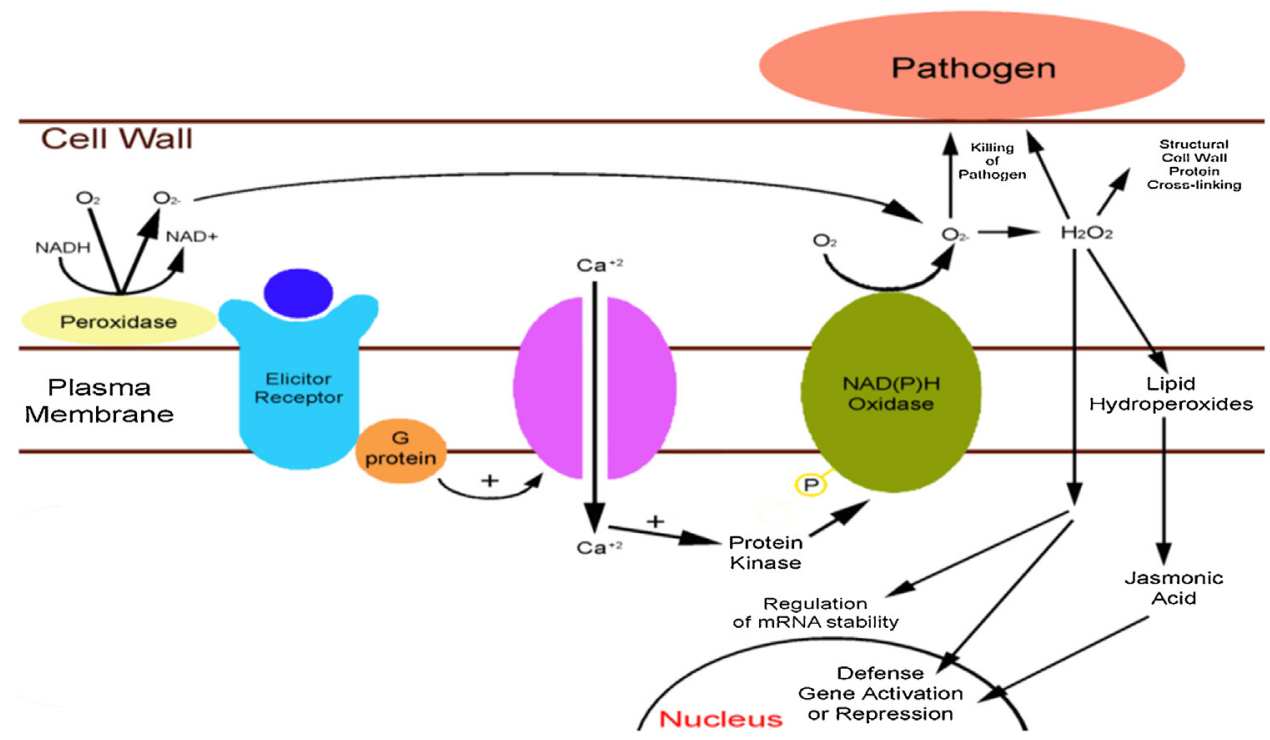

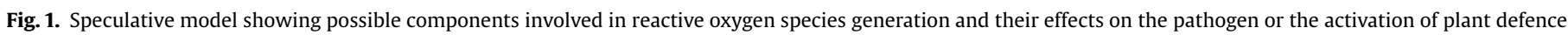
mechanisms (adapted from Mehdy, 1994).

strain of Pseudomonas syringae (Alvarez et al., 1998). These microbursts occur within two hours after an initial oxidative burst in the inoculated tissue and are followed by the formation of microscopic HR lesions. Using catalase to scavenge $\mathrm{H}_{2} \mathrm{O}_{2}$, or DPI (diphenylene iodonium) to inhibit the NADPH oxidase, it was demonstrated that both the primary and secondary oxidative bursts are required for the onset of SAR. The authors proposed that microbursts of ROS might activate defence responses at a low level throughout the plant and this contributed to the SAR-induced state (Durrant and Dong, 2004).

The most biologically important ROS are the free radicals $\mathrm{H}_{2} \mathrm{O}_{2}$ (hydrogen peroxide), $\mathrm{O}_{2}^{--}$(superoxide) and $\mathrm{OH}^{-}$(hydroxyl radicals), these are considered "active" or "reactive" because they do not require energy input to react with other molecules. The superoxide $\left(\mathrm{O}_{2}{ }^{-}\right)$can be produced in plants by many mechanisms including the activation of NADPH oxidase/synthases bound to the membrane, cell wall peroxidases, lipoxygenases, and as a result of electron transfer from mitochondria or chloroplasts. The $\mathrm{O}_{2}{ }^{-}$ usually oxidises organic molecules such as ascorbate or metals such as $\mathrm{Fe}^{3+}$ (Saathoff et al., 2013; Thakur and Sohal, 2013). Hydroxyl radicals $\left(\mathrm{OH}^{-}\right)$are extremely toxic, they are generated by $\mathrm{H}_{2} \mathrm{O}_{2}$ conversion in the presence of $\mathrm{Fe}^{2+}$ and they act in proteins reducing enzyme activity with lipids increasing the permeability of membranes and with DNA causing mutations.

$\mathrm{H}_{2} \mathrm{O}_{2}$ is predominantly generated in chloroplasts through the transfer of energy from a photo-excited chlorophyll to the molecular oxygen electron. $\mathrm{H}_{2} \mathrm{O}_{2}$ reacts easily with double bonds and has affinity with amino acids such as histidine, methionine, tryptophan, and cysteine. $\mathrm{H}_{2} \mathrm{O}_{2}$ accumulation can depend on two consecutive steps: reduction of molecular $\mathrm{O}_{2}$ to $\mathrm{O}_{2}{ }^{-}$followed by spontaneous or catalysed dismutation of $\mathrm{O}_{2}{ }^{-}$to $\mathrm{H}_{2} \mathrm{O}_{2}$ (Thakur and Sohal, 2013). The superoxide dismutase (SOD) enzyme catalyses $\mathrm{O}_{2}{ }^{-}$to $\mathrm{O}_{2}$ and $\mathrm{H}_{2} \mathrm{O}_{2}$. Hydrogen peroxide can be directly toxic to pathogens and is involved in cell wall strengthening and in the lignin biosynthesis process. It also acts as a second messenger, being responsible for the activation of the benzoic acid hydrolase, the enzyme responsible for the conversion of benzoic acid into salicylic acid.

ROS are highly reactive and toxic to the cell and to the attacker, being quickly removed from the medium by antioxidant enzymes such as superoxide dismutases, ascorbate/glutathione cycle enzymes, catalase and $\beta$-carotene (Raoni and Jyothsna, 2010;
Davar et al., 2013; Shah et al., 2014). SODs can be linked to a metal, $\mathrm{Cu} / \mathrm{Zn}, \mathrm{Mn}$ and $\mathrm{Fe}$, present in the cytosol, chloroplasts and mitochondria, respectively. The ascorbate or glutathione cycle is the main ROS removal system in the chloroplast. The enzymes involved in this cycle include: ascorbate peroxidase, dehydroascorbate reductase, monodehydroascorbate reductase and glutathione reductase (Thakur and Sohal, 2013; Raoni and Pratyusha, 2013). $\mathrm{H}_{2} \mathrm{O}_{2}$ can be reduced and removed by the ascorbate peroxidase as a reducing agent to form the monodehydroascorbate radical. This in turn will dismutate to dehydroascorbate and ascorbate. Catalases are enzymes that convert $\mathrm{H}_{2} \mathrm{O}_{2}$ to $\mathrm{H}_{2} \mathrm{O}$ and $\mathrm{O}_{2}{ }^{-}$ that are present in glycosomes and peroxisomes. Catalases are the main enzymes in plant $\mathrm{H}_{2} \mathrm{O}_{2}$ detoxification and they can dismutate $\mathrm{H}_{2} \mathrm{O}_{2}$ directly or oxidise substrates such as methanol, ethanol, formaldehyde and formic acid. The $\beta$-carotene is an effective detoxification agent of ${ }^{1} \mathrm{O}_{2}$. It participates in the antennae system of chloroplasts, in light absorption and in energy transfer to the reactions centres (Garcia-Brugger et al., 2006).

In 1998, when Alvarez et al. (1998) worked with Arabidopsis, they observed that $\mathrm{H}_{2} \mathrm{O}_{2}$ accumulated in leaves in small groups of cells after being inoculated with an avirulent agent, Pseudomonas syringae. This accumulation occurred within two hours after the initial oxidative burst in inoculated tissue, followed by the formation of microscopic lesions of hypersensitivity response. When using catalase to remove $\mathrm{H}_{2} \mathrm{O}_{2}$, or DPI (difenilenoiodonium) to inhibit NADPH oxidase, it was demonstrated that the primary and secondary oxidative bursts were required for the beginning of SAR. The authors proposed that the oxidative microbursts in reactive oxygen species can activate defence responses and contribute to SAR.

\subsection{Resistance inducers}

Exogenous application of plant resistance inducers (PRIs) able to activate plant defences is an interesting approach for new integrated pest management practices. The full integration of PRIs into agricultural practices requires methods for the fast and objective upstream screening of efficient PRIs and optimization of their application (Bernonville et al., 2014). The induction of resistance has been extensively studied in order to develop new alternatives in disease control, particularly to develop measures that will minimise the impact to the environment and to man. The 
induction of resistance can be obtained through the use of natural products, with fungal or plant origin, and it has also the advantage to allow responses to the attack of a wide range of pathogens mostly because it has no specific mechanisms of action (Madhusudhan et al., 2008; Graham and Myers, 2011).

Elicitor or inductor is defined as a molecule or molecules present in an organism or produced by the plant itself and whose functions include the generation of defence responses (Mandal, 2010). Molecules of fungi, bacteria and virus can be resistance inducers. These are mostly made up of proteins and carbohydrates present in the cells of plant pathogens.

Several studies have shown that the use of external resistance inducers activate defence mechanisms in most of the species studied. Madhusudhan et al. (2008) when using Acibenzolar-Smethyl pre-treatment to tomato and tobacco plants reduced the concentration of Tomato mosaic virus (ToMV) and Tobacco mosaic virus (TMV) through a mechanism that involves RdRp (RNAdependent RNA Polymerase) and AOX (Alternative Oxidase) gene induction.

Mandal (2010) investigated an induced resistance in eggplant (Solanum melongena L.) in respect to cell wall strengthening and defence enzyme activation affected by four resistance inducers, chitosan (CHT), salicylic acid (SA), methyl salicylate (MeSA) and methyl jasmonate (MeJA). The increase in total phenolic content and lignin eposition in the cell wall of eggplant roots by the resistance inducers was significantly higher. Phenylalanine ammonia-lyase (PAL) activity showed an increase. Highest activity of peroxidase (POD) was observed at $24 \mathrm{~h}$ after elicitation under the precise influence of CHT and SA. The activities of polyphenol oxidase (PPO), cinnamyl alcohol dehydrogenase (CAD) and catalase (CAT) were also increased several folds by the resistance inducers. Accumulation of phenolics and lignin in high amounts, together with higher activity of major defence enzymes in response to the resistance inducers, may bolster eggplants in mounting practical and effective resistance against Ralstonia solanacearum, a devastating pathogen that causes plant wilt.

De Meyer et al. (1998) provided arguments for the participation of induced plant defence in Trichoderma harzianum T39 control of Botritis cinerea in tomato, lettuce, pepper, bean and tobacco, which resulted in a $25-100 \%$ reduction of grey mould symptoms, caused by a delay or suppression of spreading lesion formation.

Elsharkawy et al. (2013) evaluated T. asperellum SKT-1 for induction of resistance against yellow strain of Cucumber mosaic virus (CMV-Y) in Arabidopsis plants. Disease severity was rated at 2 weeks post inoculation (WPI). CMV titre in Arabidopsis leaves was determined by indirect enzyme-linked immunosorbent assay (ELISA) at 2 WPI. Their results demonstrated that among all Arabidopsis plants treated with barley grain inoculum (BGI) of SKT1 NahG and npr1 plants showed no significant reduction in disease severity and CMV titre as compared with control plants. In contrast, disease severity and CMV titre were significantly reduced in all Arabidopsis plants treated with culture filtrate (CF) of SKT1 as compared with control plants. RT-PCR results showed increased expression levels of SA-inducible genes, but not JA/ETinducible genes, in leaves of BGI treated plants. Moreover, expression levels of SA- and JA/ET inducible genes were increased in leaves of $\mathrm{CF}$ treated plants. In conclusion, BGI treatment induced systemic resistance against CMV through SA signalling cascade in Arabidopsis plants. While, treatment with CF of SKT- 1 mediated the expression of a majority of the various pathogen related genes, which led to the increased defence mechanism against CMV infection.

Harpins are glycine-rich and heat-stable proteins that are secreted through type III secretion system in gram-negative plantpathogenic bacteria. Many studies show that these proteins are mostly targeted to the extracellular space of plant tissues, unlike bacterial effector proteins that act inside the plant cells. The first harpin of pathogen origin, HrpN of Erwinia amylovora, was reported in 1992 as a cell-free elicitor of hypersensitive response (HR). Some harpins were shown to have virulence activity, probably because of their involvement in the translocation of effector proteins into plant cytoplasm. Based on this function, harpins are now considered to be translocators. Their abilities of pore formation in the artificial membrane, binding to lipid components, and oligomerization are consistent with this idea. When harpins are applied to plants directly or expressed in plant cells, these proteins trigger diverse beneficial responses such as induction of defence responses against diverse pathogens and enhancement of plant growth (Choi et al., 2006).

Obradovic et al. (2005) studied two strains of plant growthpromoting rhizobacteria, two systemic acquired resistance inducers (harpin and acibenzolar-S-methyl), host-specific unformulated bacteriophages, and two antagonistic bacteria for control of tomato bacterial spot incited by Xanthomonas campestris pv vesicatoria in greenhouse experiments. The results showed that when plant growth-promoting rhizobacteria strains were applied alone or in combination with other treatments, they had no significant effect on bacterial spot intensity. Antagonistic bacterial strains, when applied alone, had negligible effects on disease intensity. Acibenzolar-S-methyl completely prevented occurrence of typical symptoms of the disease, however necrotic spots typical of a hypersensitive reaction (HR) were observed on plants treated with acibenzolar-S-methyl alone. Electrolyte leakage and population dynamics experiments confirmed that acibenzolar-S-methyltreated plants responded to inoculation by eliciting an HR. Application of bacteriophages in combination with acibenzolarS-methyl suppressed a visible HR and provided excellent disease control. These authors concluded that thentegrated use of acibenzolar-S-methyl and phages may complement each other as an alternative management strategy against bacterial spot on tomato.

The efficacy of hexanoic acid (Hx) as an inducer of resistance in tomato plants against Pseudomonas syringae pv. tomato DC3000 was demonstrated by Scalschi et al. (2014) and the plant response was characterized. Their work provided the first demonstration of the response of the pathogen to the changes observed in plants after $\mathrm{Hx}$ application not only in terms of the population size but also of the transcriptional levels of genes involved in quorum sensing establishment and pathogenesis. It is possible that $\mathrm{Hx}$ treatment attenuates the virulence and survival of bacteria by preventing or diminishing the appearance of symptoms and controlling the growth of the bacteria in the mesophyll. Hx is able to alter bacteria pathogenesis and survival only when it is applied as a resistance inducer because the changes it promotes in plants affect the bacteria.

The best known commercial resistance inducer is ASM (Dietrich et al., 2005), which is a structural and functional analogue of salicylic acid. It induces resistance in various plant species against a broad spectrum of pathogenic viruses, bacteria, fungi and nematodes. Studies using this elicitor demonstrate rapid expression of resistance-related genes such as glucanases and chitinases (Dietrich et al., 2005). Comparative studies are being done in an attempt to obtain a new commercial resistance inducer due to the wide use of ASM and to understand the defence mechanisms activated with the use of these products.

ASM and other commercial inducers of resistance have been extensively evaluated as components for plant disease control in the field (Vallad and Goodman, 2004); however, their effectiveness for practical application in disease management has been questioned due to variability of control (Walters and Fountaine, 2009). Field studies showing promising results for control of bacterial diseases have been conducted with foliar sprays of ASM 
either alone or in combination with copper on tomato and pepper (Louws et al., 2001; Romero et al., 2001). For citrus, foliar application of ASM was effective against citrus canker under greenhouse conditions but foliar sprays of ASM combined or alternated with copper oxychloride did not contribute to the control of canker on sweet orange trees in field trials (Graham and Leite, 2004). Expression of the PR protein ( $\beta-1,3$ glucanase) gene, $P R-2$, in citrus increased in response to ASM and isonicotinic acid (INA). However, PR-2 response and reduction of lesions after foliar sprays was sustained for only a few weeks (Dekkers et al., 2004). Likewise, ASM induced acidic PR-1 expression in tomato for 7-10 days (Herman and Restrepol, 2007), confirming that foliar applications at weekly intervals are required for field control of Xanthomonas leaf spot and Pseudomonas bacterial speck on tomato (Louws et al., 2001).

\section{Conclusions}

The protection of plants against pathogens through induced resistance can be made through the use of exogenous substances. It is likely that induced resistance against diseases either through chemical activators or other means will become an important component of pest management programs, particularly in cases where current control measures are little effective. Obviously, one of the outcomes of the use of this new technology should be a reduction of the use of traditional pesticides, which is of a major concern regarding the preservation of the environment.

However, more studies are needed regarding the defence mechanisms that are activated in each case, and the responses that are triggered so that these resistance inducers may be released to the market. And most importantly, it is essential to understand that resistance inducers do not perform miracles and it is still needed an integrated management to reduce to the lowest the losses caused by diseases.

\section{Acknowledgements}

Mônica D.M. Oliveira received a post-doctoral fellowship from Coordenação de Aperfeiçoamento de Pessoal de Nível Superior (CAPES): CsF/2581/31-2. Carla M. R. Varanda received a postdoctoral fellowship from Foundation for Science and Technology (FCT): SFRH/BPD/76194/2011, funded by QREN - POPH -Typology 4.1 - co-funded by MES National Funding and The European Social Fund. This work has been supported by National funds, through the Programa Operacional Regional do Alentejo (InAlentejo) Operation ALETN-07-0262-FEDER-001871/Laboratório de Biotecnologia Aplicada e Tecnologias Agro-Ambientais.

\section{References}

Abdel-Kader, M.M., El-Mougy, N.S., Lashin, S.M., 2013. Biological and chemical resistance inducers approaches for controlling foliar diseases of some vegetables under protected cultivation system. J. Plant Pathol. Microb. 4 (9), 200. doi:http://dx.doi.org/10.4172/2157-7471.1000200.

Agrios, G.N., 2005. Plant Pathology, 5th edition Academic Press, San Diego, Calif, USA.

Alarcon, J.J., Malone, M., 1995. The influence of plant age on wound induction of proteinase inhibitors in tomato. Physiol. Plant 95, 423-427.

Alvarez, M.E., Pennell, R.I., Meijer, P.J., Ishikawa, A., Dixon, R., Lamb, C., 1998. Reactive oxygen intermediates mediate a systemic signal network in the establishment of plant immunity. Cell 92, 773-784.

Aryal, S.K., Davis, R.F., Stevenson, K.L., Timper, P., Ji, P., 2011. Influence of infection of cotton by Rotylenchulus reniformis and Meloidogyne incognita on the production of enzymes involved in systemic acquired resistance. J. Nematol. 43 (3-4), 152 159.

Bernonville, T.D., Marolleau, B., Staub, J., Gaucher, M., Brisset M-, N., 2014. Using molecular tools to decipher the complex world of plant resistance inducers: an apple case study. J. Agric. Food Chem. 62, 11403-11411.

Bettini, P., Cosi, E., Pellegrini, M.G., Turbanti, L., Vendramin, G.G., Buiatti, M., 1998 Modification of competence for in vitro response to Fusarium oxysporum in tomato cells, III. PR-protein gene expression and ethylene evolution in tomato cell lines transgenic for phytohormone-related bacterial genes. Theor. Appl. Genet. 98, 575-583.

Bostock, R.M., 1999. Signal conflicts and synergies in induced resistence to multiple attackers. Physiol. Mol. Plant Pathol. 55, 99-109.

Bostock, R.M., 2005. Signal crosstalk and induced resistance: Straddling the between cost and benefit. Ann. Rev. Phytopathol. 43, 545-580.

Bowles, D.J., 1990. Defense-related proteins in higher plants. Ann. Rev. Biochem. 59, 873-907.

Buchanan, B.B., Gruissem, W., Jones, R.L., 2000. Biochemistry and molecular biology of plants. Rockv. Am. Soc. Plant Physiol.

Cameron, R.K., 2000. Salicilyc acid and its role in plant defence responses: what do we really know. Physiol. Mol. Plant Pathol. 56, 91-93.

Cheong, Y.H., Kim, C.Y., Chun, H.J., Moon, B.C., Park, H.C., Kim, J.K., Lee, S.H., Han, C.D., Lee, S.Y., Cho, M.J., 2000. Molecular cloning of a soybean class III $\beta$-1,3-glucanase gene that is regulated both developmentally and in response to pathogen infection. Plant Sci. 154, 71-81.

Choi, YJ., Lee, G., Park, J.H., 2006. Programmed cell death mechanisms of identifiable peptidergic neurons in Drosophila melanogaster. Development 133, 2223-2232.

Conrath, U., Beckers, G.J.M., Flors, V., Garcia-Agustin, P., Jakab, G., Mauch, F., 2006. Priming getting ready for battle. Mol. Plant-Microbe Interact. 19, 1062-1071.

Davar, R., Darvishzadeh, R., Majd, A., 2013. Changes in antioxidant systems in sunflower partial resistant and susceptible lines as affected by Sclerotinia sclerotiorum. Biol 68, 821-829.

Dekkers, M.G.H., Graham, J.H., Burns, J.K., Cubero, J., Colburn, G.C. 2004. Evaluation of chemical inducers and PR protein reporters for induced systemic resistance to citrus bacterial diseases. Abstr.) Phytopathology 94, S25.

Delaney, T.P., 1997. Genetic dissection of acquired resistance to disease. Plant Physiol. 113, 5-12.

De Meyer, G., Bigirimana, J., Elad, Y., Höfte, M., 1998. Induced systemic resistance in Trichoderma harzianum T39 biocontrol of Botritis cinerea. Eur. J. Plant Pathol. 104, 279-286.

Dietrich, R., Ploss, K., Heil, M., 2005. Growth responses and fitness cost after induction of pathogen resistance depend on environmental condition. Plant Cell Environ. 28, 211-222.

Dixon, R.A., Harrison, M.J., Lamb, C.J., 1994. Early events in the activation of plant defence responses. Ann. Rev. Phytopathol. 32, 479-501.

Durrant, W.E., Dong, X., 2004. Systemic acquired resistance. Ann. Rev. Phytopathol. 42, 185-209.

Ebrahim, S., Usha, K., Singh, B., 2011. Pathogenesis related (PR) proteins in plant defense mechanism. In: Méndez-Vilas, A. (Ed.), Science Against Microbial Pathogens: Communicating Current Research and Technological Advances. Formatec, pp. 1043-1054.

Elsharkawy, M.M., Shimizu, M., Takahashi, H., Ozaki, K., Hyakumachi, M., 2013. Induction of systemic resistance against Cucumber mosaic virus in Arabidopsis thaliana by Trichoderma asperellum SKT-1. Plant Pathol. 29 (2), 193-200.

Farouk, S., Osman, M.A., 2011. The effect of plant defense elicitors on common bean (Phaseolus vulgaris L.) growth and yield in absence or presence of spider mite (Tetranychus urticae Koch) infestation. J. Stress Physiol. Biochem. 7 (3), 05-22.

Garcia-Brugger, A., Lamotte, O., Vandelle, E., 2006. Early signalling events induced by elicitors of plant defenses. Mol. Plant Microbe Interact. 19 (7), 711-724.

Gill, S.S., Tuteja, N., 2010. Reactive oxygen species and antioxidant machinery in abiotic stress tolerance in crop plants. Plant Physiol. Biochem. 48, 909-930.

Gómez-Vásquez, R., Day, R., Buschmann, H., Randles, S., Beeching, J.R., Cooper, R.M., 2004. Phenylpropanoids, phenylalanine ammonia lyase and peroxidases in elicitor-challenged cassava (Maninhot esculenta) suspension cells and leaves. Ann. Bot. 94 (1), 87-97.

Graham, J.H., Leite, R.P., 2004. Lack of control of citrus canker by induced systemic resistance compounds. Plant Dis. 88, 745-750.

Graham, J.H., Myers, M.E., 2011. Soil application of SAR inducers imidacloprid, thiamethoxam, and acibenzolar-S-methyl for citrus canker control in young grapefruit trees. Plant Dis. 95, 725-728.

Heil, M., Bostock, M.R., 2002. Induced systemic resistance (ISR) against pathogens in the context of induced plant defences. Ann. Bot. 89, 503-512.

Herman, M.A.B., Restrepo1, C.D., 2007. Smart CD. Defense gene expression patterns of three SAR-induced tomato cultivars in the field. Physiol. Mol. Plant Pathol. 71, 192-200.

Jach, G., Gornhardt, B., Mundy, J., Logemann, J., Pinsdorf, E., Leah, R., Schell, J., Maas, C., 1995. Enhanced quantitative resistance against fungal disease by combinatorial expression of different barley antifungal proteins in transgenic tobacco. Plant J. 8, 97-109.

Jones, J.D.G., Dangl, J.L., 2006. The plant immune system. Nature 444, 323-329.

Lambais, M.R., Mehdy, M.C., 1998. Spatial distribution of chitinases and $\beta-1,3-$ glucanase transcripts in bean arbbuscular mycorrhizal roots under low and high soil phosphate conditions. New Phytol. 140, 33-42.

Legrand, M., Kauffmann, S., Geoffroy, P., Fritig, B., 1987. Biological function of pathogenesis-related proteins: four tobacco pathogenesis-related proteins are chitinases. Proc. Natl. Acad. Sci. 84, 6750-6754.

Leubner-Metzger, G., Meins, F.J., 1999. Functions and regulation of plant $\beta-1,3-$ glucanases (PR-2). In: Datta, S.K., Muthukrishnan, S. (Eds.), PathogenesisRelated Proteins in Plants. CRC Press, Boca Raton, Florida, pp. 77-105.

Li, W.L., Faris, J.D., Muthukrishnan, S., Liu, D.J., Chen, P.D., Gill, B.S., 2001. Isolation and characterization of novel cDNA clones of acidic chitinases and $\beta-1,3-$ glucanases from wheat spikes infected by Fusarium graminearum. Theor. Appl. Genet. 102, 353-362. 
Liu, J.J., Ekramoddoullah, A.K.M., 2006. The family 10 of plant pathogenesis-related proteins: Their structure, regulation, and function in response to biotic and abiotic stresses. Physiological and Mol. Plant Pathol. 68, 3-13.

Louws, F.J., Wilson, M., Campbell, H.L., Cuppels, D.A., Jones, J.B., Shoemaker, P.B. Sahin, F., Miller, S.A., 2001. Field control of bacterial spot and bacterial speck of tomato using a plant activator. Plant Dis. 85, 481-488.

Lyon, G.D., Newton, A.C., 2007. Do resistance elicitors offer new opportunities in integrated disease control strategies? Plant Pathol. 46, 636-641.

Madhusudhan, K.N., Deepak, S.A., Prakash, H.S., Agrawal, G.K., Jwa, N.S., Rakwal, R., 2008. Acibenzolar-S-methyl (ASM)-induced resistance against tobamoviruses involves induction of RNA-Dependent RNA polymerase (RdRp) and alternative oxidase (AOX) genes. J. Cop. Sci. Biotech. 11 (2), 127-134.

Mandal, S., 2010. Induction of phenolics, lignina and key defense enzymes in eggplant (Solanum melongena L.) roots in response to elicitors. Afr. J. Biotechnol. 9 (47), 8038-8047.

Mauch, F., Hadwiger, L.A., Boller, T., 1988a. Antifungal hydrolases in pea tissue I. Purification and characterization of two chitinases and two beta-1,3-glucanases differentially regulated during development and in response to fungal infection. Plant Physiol. 87, 325-333.

Mauch, F., Mauch-Mani, B., Boller, T., 1988b. Antifungal hydrolases in pea tissue. II. Inhibition of fungal growth by combinations of chitinase and $\beta-1,3$-glucanase. Plant Physiol. 88, 936-942.

Mehdy, M.C., 1994. Active oxygen species in plant defense against pathogens. Plant Physiology 105, 467-472.

Neuhaus, J.M., 1999. Plant chitinases (PR-3, PR-4, PR-8, PR-11). In: Datta, S.K. Mathukrishnan, S. (Eds.), Pathogenesis Related Proteins in Plants. CRC Press, Boca Raton, pp. 77-105.

Neuenschwander, U., Vernooij, B., Friedrich, L., Uknes, S., Kessmann, H., Ryals, J., 1995. Is hydrogen peroxide a second messenger of salicylic acid in systemic acquired resistance? Plant J. 8, 227-233.

Niki, T., Mitsuhara, I., Seo, S., Ohtsubo, N., Ohashi, Y., 1998. Antagonistic effect of salicylic acid and jasmonic acid on the expression of pathogenesis-related (PR) protein genes in wounded mature tobacco leaves. Plant Cell Physiol. 39, 500507.

Obradovic, A., Jones, J.B., Momol, M.T., Jackson, S.M., Balogh, L.E., Guven, K., Iriarte, F. B., 2005. Integration of biological control agents and systemic acquired resistance inducers against bacterial spot on tomato. Plant Dis. 89, 712-716.

O'Brien, J.A., Daudi, A., Butt, V.S., Bolwell, G.P., 2012. Reactive oxygen species and their role in plant defence and cell wall metabolism. Planta 236, 765-779.

Petruzzelli, L., Kunz, C., Waldvogel, R., Meins, F., Leubner-Metzger, G., 1999. Distinct ethylene and tissue-specific regulation of $\beta-1,3-$ glucanases and chitinases during pea seed germination. Planta 209, 195-201.

Raoni, P.U., Jyothsna, Y., 2010. Biochemical and enzymatic changes in rice plants as a mechanism of defence. Acta Physiol. Plant 32, 695-701.

Raoni, P.U., Pratyusha, S., 2013. Defensive role of Gossypium hirsutum L. antioxidative enzymes and phenolic acids in response to Spodoptera litura F. feeding. J. Asia Pac. Entomol. 16, 131-136.

Romero, A.M., Kousik, C.S., Ritchie, D.F., 2001. Resistance to bacterial spot in bell pepper induced by acibenzolar-S-methyl. Plant Dis. 85, 189-194.
Ryals, J., Lawton, K.A., Delaney, T.P., Friedrich, L., Kessmann, H., 1995. Signal transduction in systemic acquired resistance. Proc. Natl. Acad. Sci. U. S. A. 92, 4202-4205.

Ryals, J.A., Neuenschwander, U.H., Willits, M.G., Molina, A., Steiner, H.Y., Hunt, M.D. 1996. Systemic acquired resistance. Plant Cell 8, 1809-1819.

Saathoff, A.J., Donze, T., Palmer, N.A., Bradshaw, J., Heng-Moss, T., Twigg, P., Tobias, C. M., Lagrimini, M., Sarath, G., 2013. Towards uncovering the roles of switchgrass peroxidases in plant processes. Front. Plant Sci. 4, 1-12.

Scalschi, L., Camañes, G., Llorens, E., Fernández-Crespo, E., López, M.M., GarcíaAgustín, P., Vicedo, B., 2014. Resistance inducers modulate Pseudomonas syringae pv. tomato strain DC 3000 response in tomato plants. PloS One 9 (9), e106429.

Sels, J., Mathys, J., De Coninck, B.M., Cammue, B.P., De bolle, M.F., 2008. Plant pathogenesis-related (PR) proteins: a focus on PR peptidest pathogenesisrelated (PR) proteins: a focus on PR peptides. Plant Physiol. Biochem. 46 (11) 941-950.

Shah, J., Chaturvedi, R., Chowdhury, Z., Venables, B., Petros, R.A., 2014. Signaling by small metabolites in systemic acquired resistance. Plant J. 2007 79, 645-658.

Shah, J., Zeier, J., 2013. Long-distance communication and signal amplification in systemic acquired resistance. Front. Plant Sci. 4 (30) .

Shewry, P.R., Lucas, J.A., 1997. Plant proteins that confer resistance to pests and pathogens: advances in botan. Res. Incorp. Adv. Plant Pathol. 26, 135-192.

Thakur, M., Sohal, B.S., 2013. Role of elicitors in inducing resistance in plants against pathogen infection: a review. ISRN Biochem. 1-11.

Torres, M.A., 2010. ROS in biotic interactions. Physiol. Plant 138, 414-429.

Vallad, G.E., Goodman, R.M., 2004. Systemic acquired resistance and induced systemic resistance in conventional agriculture. Crop Sci. 44, 1920-1934.

Van Loon, L.C., Van Kammen, A., 1970. Polyacrylamide disc electrophoresis of the soluble leaf proteins from Nicotiana tabacum var 'Samsun' and Samsun NN II. Changes in protein constitution after infection with tobacco mosaic virus. Virology 40, 199-211.

Van Loon, L.C., 1985. Pathogenesis-related proteins. Plant Mol. Biol. 4, 111-116.

Van Loon, L.C., Bakker, P.A.H.M., Pieterse, C.M.J., 1998. Systemic resistance induced by rhizosphere bacteria. Ann. Rev. Phytop. 36, 453-483.

Van Loon, L.C., Van Strien, E.A., 1999. The families of pathogenesis-related proteins, their activities, and comparative analysis of PR- 1 type proteins. Physiol. Mol. Plant Pathol. 55 (2), 85-97.

Vandenborre, G., Smagghe, G., Van Damme, E.J.M., 2011. Plant lectins as defence proteins against phytophagous insects. Phytochemistry 72, 1538-1550.

Vogelsang, R., Barz, W., 1993. Purification, characterization and differential hormonal regulation of a $\beta-1,3$-glucanase and two chitinases from chickpea (Cicer arietinum L.). Planta 189, 60-69.

Walters, D., Newton, A., Lyon, G., 2007. Induced Resistance for Plant Defence-A Sustainable Approach to Crop Protection. Blackwell, Oxford.

Walters, D.R., Fountaine, J.M., 2009. Practical application of induced resistance to plant diseases: an appraisal of effectiveness under field conditions. J. Agric. Sci. $147,523-535$. 